\title{
PRIORITAS PENINGKATAN JALAN DI KABUPATEN PIDIE JAYA BERBASIS ANALYTICAL HIERARCHY PROCESS (AHP)
}

\author{
Y. Mahendra ${ }^{1)}$, R. Anggraini ${ }^{2)}$, A. T. Bulba ${ }^{3)}$ \\ Magister Teknik Sipil, Universitas Syiah Kuala, Banda Aceh \\ email:muraiatjeh@gmail.com ${ }^{1)}, \underline{\text { renni.anggraini@gmail.com }}{ }^{2)}$ \\ alfatarasbulba@unsyiah.ac.id ${ }^{3)}$
}

DOI: http://dx.doi.org/10.29103/tj.v11i1.430

(Received: December 2020 / Revised: January 2021 / Accepted: January 2021)

\begin{abstract}
Abstrak
Dinas Pekerjaan Umum Kabupaten Pidie Jaya, telah mengusulkan peningkatan jalan ke Kementerian Pekerjaan Umum dan Perumahan Rakyat Republik Indonesia sebanyak 5 ruas untuk ditingkatkan pada tahun 2021 dengan total biaya sebesar Rp. 16.731.593.750. Usulan peningkatan jalan tersebut di tahun 2021 tidak dapat ditingkatkan semua, karena adanya keterbatasan anggaran. Keterbatasan anggaran disebabkan adanya refocusing anggaran untuk penanganan Corona Virus Disease 2019 (Covid 19) di Indonesia. Penelitian ini bertujuan untuk menganalisis kriteria yang dominan perlu dipertimbangkan dalam peningkatan jalan di Kabupaten Pidie Jaya dan menganalisis urutan prioritas peningkatan jalan di Kabupaten Pidie Jaya berdasarkan kriteria kerusakan jalan, biaya peningkatan, dan tata guna lahan. Penelitian ini menggunakan pendekatan metode kuantitatif melalui kuesioner.Data primer yang digunakan adalah data kuesioner. Pengumpulan data kuesioner dilakukan dengan menjumpai langsung keberadaan responden.Responden dalam penelitian ini ditetapkan sebanyak 5 stakeholders yaitu Kepala Bidang Bina Marga Dinas Pekerjaan Umum Kabupaten Pidie Jaya, Kepala Bidang Perencanaan Sarana dan Prasarana Badan Perencanaan Pembangunan Daerah Kabupaten Pidie Jaya, Kepala Bidang Perhubungan Jalur Darat Dinas Perhubungan Kabupaten Pidie Jaya, Anggota Komisi D Bidang Pembangunan Dewan Perwakilan Rakyat Kabupaten Pidie Jaya, dan Akademisi Universitas Syiah Kuala. Kriteria yang ditinjau adalah kerusakan jalan, biaya peningkatan, dan tata guna lahan. Alternatif yang ditinjau adalah Jalan Blang Dalam - Jurong Teungoh, Jalan Jeulanga Barat - Jeulanga Mata Ie, Jalan Simpang Pertanian - Cot Trieng - Rungkom, Jalan Trienggadeng - Panton Beurasan - Cubo, dan Jalan Meurandeh Alue - Asan Kumbang - Blang Miroe.Teknik analisis data digunakan statistik deskriptif dan Analytical Hierarchy Process (AHP). Hasil penelitian menunjukkan bahwa kriteria yang dominan perlu dipertimbangkan dalam peningkatan jalan adalah kriteria biaya peningkatan dengan nilai rata-rata gabungan eigen sebesar 0,49. Prioritas peningkatan jalan berdasarkan kriteria kerusakan jalan, biaya peningkatan, dan tata guna lahan adalah Jalan Meurandeh Alue - Asan Kumbang - Blang Miroe sebagai prioritas 1 dengan bobot sebesar 0,38 dan Jalan Trienggadeng - Panton Beurasan - Cubo sebagai prioritas 2 dengan bobot sebesar 0,25 .
\end{abstract}

Kata kunci: prioritas, kerusakan jalan, biaya peningkatan, tata guna lahan

\begin{abstract}
The Public Works Office of Pidie Jaya Regency has proposed 5 sections to increase the road to the Ministry of Public Works and Public Housing of the Republic of
\end{abstract}


Indonesia to be upgraded in 2021 with a total cost Rp. 16,731,593,750. All of the proposed road improvements in 2021 cannot be upgraded, due to budget constraints. The budget limitation is due to refocusing the budget for handling Corona Virus Disease 2019 (Covid 19) in Indonesia. This study aims to analyze the dominant criteria that need to be considered in road improvement in Pidie Jaya Regency and to analyze the order of priority for road improvement in Pidie Jaya Regency based on the criteria for road damage, improvement costs, and land use. This study uses a quantitative method approach through a questionnaire. The primary data used is questionnaire data. The questionnaire data was collected by directly seeing the respondents. Respondents in this study were assigned as many as 5 stakeholders, namely the Head of the Bina Marga Division of the Public Works Office of Pidie Jaya Regency, the Head of the Planning for Facilities and Infrastructure of the Regional Development Planning Agency of Pidie Jaya Regency, the Head of the Land Line Transportation Division of the Pidie Jaya Regency Transportation Service, a Member of the Commission D Development Sector Pidie Jaya Regency People's Representative Council, and Syiah Kuala University Academics. The criteria reviewed are road damage, cost of upgrading, and land use. The alternatives reviewed are Jalan Blang Dalam - Jurong Teungoh, Jalan Jeulanga Barat - Jeulanga Mata Ie, Jalan Simpang Pertanian - Cot Trieng - Rungkom, Jalan Trienggadeng - Panton Beurasan Cubo, and Jalan Meurandeh Alue - Asan Kumbang - Blang Miroe. The data analysis technique used descriptive statistics and Analytical Hierarchy Process (AHP). The results show that the dominant criterion that needs to be considered in road improvement is the cost of improvement criteria with a combined average eigenvalue of 0.49. Road improvement priorities based on the criteria for road damage, improvement costs, and land use are Meurandeh Alue - Asan Kumbang - Blang Miroe Road as priority 1 with a weight of 0.38 and Jalan Trienggadeng - Panton Beurasan Cubo as priority 2 with a weight of 0.25 .

Keywords: Priority, road damage, cost of improvement, land use

\section{Latar Belakang}

Jalan sebagai sistem transportasi nasional mempunyai peranan penting terutama dalam mendukung aspek ekonomi, sosial budaya, lingkungan, politik, serta pertahanan dan keamanan. Dari aspek ekonomi, keberadaan jalan diperlukan sebagai modal masyarakat untuk mempercepat proses produksi, pasar, dan konsumen akhir. Dari aspek sosial budaya, keberadaan jalan dapat membuka cakrawala masyarakat sebagai wahana perubahan sosial, membangun toleransi, dan mencairkan sekat budaya. Dari aspek lingkungan, keberadaan jalan diperlukan untuk mendukung pembangunan yang berkelanjutan. Dari aspek politik, keberadaan jalan dapat menghubungkan dan mengikat antar daerah. Dari aspek pertahanan dan keamanan, keberadaan jalan dapat memberikan akses dan mobilitas dalam penyelenggaraan sistem pertahanan dan keamanan. Mengingat pentingnya peranan jalan, maka pemerintah perlu melakukan peningkatan jalan. Peningkatan jalan adalah salah satu kegiatan penanganan jalan guna untuk meningkatkan struktur dan kapasitas jalan.

Dana Alokasi Khusus (DAK) adalah pendapatan daerah yang diperoleh dari Anggaran Pendapatan Belanja Negara (APBN) yang dimaksudkan untuk membantu kegiatan-kegiatan khusus di daerah tertentu yang menjadi urusan daerah dan sesuai prioritas nasional (Anggoro, 2017).Berdasarkan data usulan rencana kegiatan DAK tahun 2020, Dinas Pekerjaan Umum (PU) Kabupaten Pidie Jaya telah mengusulkan peningkatan jalan ke Kementerian Pekerjaan Umum dan Perumahan Rakyat (PUPR) Republik Indonesia sebanyak 5 ruas untuk ditingkatkan pada tahun 2021. Kegiatan peningkatan diusulkan pada ruas Jalan 
Blang Dalam - Jurong Teungoh, Jalan Jeulanga Barat - Jeulanga Mata Ie, Jalan Simpang Pertanian - Cot Trieng - Rungkom, Jalan Trienggadeng - Panton Beurasan - Cubo, dan Jalan Meurandeh Alue - Asan Kumbang - Blang Miroe. Jumlah total biaya peningkatan jalan tersebut adalah sebesar Rp. 16.731.593.750 (enam belas milyar tujuh ratus tiga puluh satu juta lima ratus sembilan puluh tiga ribu tujuh ratus lima puluh rupiah).

Permasalahan dalam penelitian ini adalah usulan peningkatan jalan tersebut di tahun 2021 tidak dapat ditingkatkan semua, karena adanya keterbatasan anggaran. Keterbatasan anggaran disebabkan oleh adanya refocusing anggaran untuk penanganan Corona Virus Disease 2019 (Covid 19) di Indonesia. Implikasi dari adanya refocusing tersebut adalah biaya peningkatan jalan untuk tahun 2021 di Kabupaten Pidie Jaya hanya dapat dialokasi sebesar Rp. 9.666.880.000 (sembilan milyar enam ratus enam puluh enam juta delapan ratus delapan puluh ribu rupiah). Oleh karena itu 5 ruas peningkatan jalan yang diusulkan, perlu ditentukan skala prioritas guna melihat ruas jalan mana yang paling penting ditingkatkan demi kepentingan publik untuk tahun 2021. Skala prioritas adalah proses pertimbangan berbagai kriteria dalam menentukan sebuah keputusan. Beberapa kriteria peningkatan jalan yang perlu dipertimbangkan adalah kerusakan jalan, biaya peningkatan, dan tata guna lahan. Setiap kriteria tersebut mempunyai karakteristik yang berbeda-beda pada setiap ruas peningkatan. Oleh karena itu dengan mempertimbangkan beberapa kriteria tersebut, maka dapat menentukan skala prioritas melalui penggunaan metode sistem pengambilan keputusan melalui Analytical Hierarchy Process (AHP). AHP adalah analisis yang mampu mengambil keputusan dengan mempertimbangkan seluruh kriteria yang ada sekompreherensif mungkin dalam penentuan prioritas. Tujuan dari penelitian ini adalah menganalisis kriteria yang dominan perlu dipertimbangkan dalam peningkatan jalan di Kabupaten Pidie Jaya dan menganalisis urutan prioritas peningkatan jalan di Kabupaten Pidie Jaya berdasarkan kriteria kerusakan jalan, biaya peningkatan, dan tata guna lahan.

\section{Metode Penelitian}

\subsection{Objek dan Lokasi Penelitian}

Objek dalam penelitian ini adalah ruas jalan yang tercantum di dalam usulan rencana kegiatan Dana Alokasi Khusus (DAK) tahun 2020 di Kabupaten Pidie Jaya. Lokasi penelitian seperti diperlihatkan pada Gambar 1.

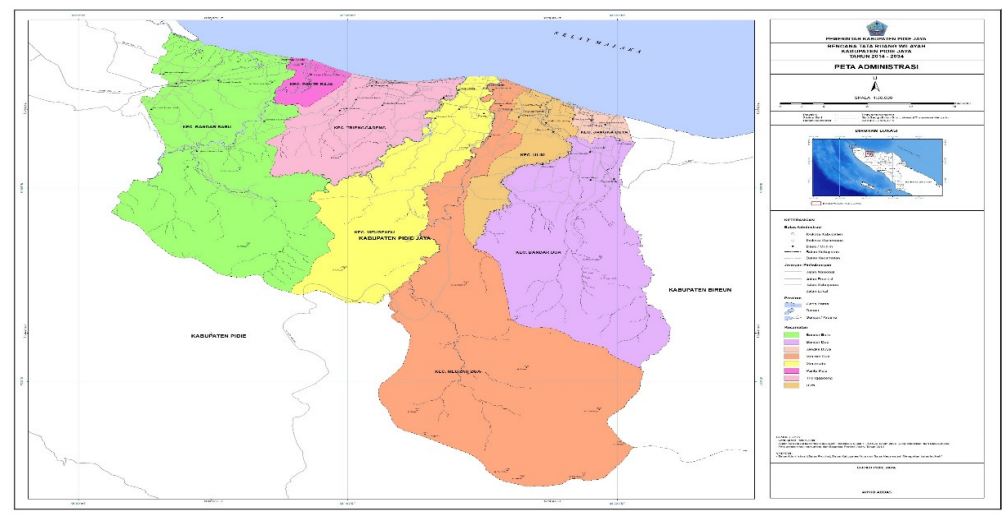

Gambar 1 Lokasi penelitian di Kabupaten Pidie Jaya

Prioritas Peningkatan Jalan di Kabupaten Pidie Jaya Berbasis Analytical Hierarchy Process (AHP) - Y. Mahendra, R. Anggraini, A. T. Bulba 
Peningkatan jalan yang diusulkan di Kabupaten Pidie Jaya terdapat sebanyak 5 ruas. Adapun lokasi ruas jalan tersebut dapat dilihat pada Tabel 1.

Tabel 1 Lokasi penelitian

\begin{tabular}{clc}
\hline No. & \multicolumn{1}{c}{ Pembangunan Jembatan } & \multicolumn{1}{c}{ Lokasi } \\
\hline 1 & Jalan Blang Dalam - Jurong Teungoh & Kecamatan Bandar Dua \\
\hline 2 & Jalan Jeulanga Barat - Jeulanga Mata Ie & Kecamatan Bandar Dua \\
\hline 3 & Jalan Simpang Pertanian - Cot Trieng - Rungkom & Kecamatan Meureudu \\
\hline 4 & Jalan Trienggadeng - Panton Beurasan - Cubo & Kecamatan Trienggadeng \\
\hline 5 & $\begin{array}{l}\text { Jalan Meurandeh Alue - Asan Kumbang - Blang } \\
\text { Miroe }\end{array}$ & Kecamatan Bandar Dua \\
\hline
\end{tabular}

\subsection{Teknik Penentuan Sampel}

Teknik penentuan sampel yang digunakan adalah purposive sampling. Purposive sampling adalah teknik pengambilan sampel dengan pertimbangan didasarkan pada pemangku kepentingan dan pengambil kebijakan (stakeholders) yang mengetahui kondisi kriteria pada lokasi usulan peningkatan jalan di Kabupaten Pidie Jaya. Jumlah sampel dalam penelitian ini ditetapkan sebanyak 5 stakeholders, yaitu Kepala Bidang Bina Marga Dinas PU Kabupaten Pidie Jaya, Kepala Bidang Perencanaan Sarana dan Prasarana Bappeda Kabupaten Pidie Jaya, Kepala Bidang Perhubungan Jalur Darat Dinas Perhubungan Kabupaten Pidie Jaya, Anggota Komisi D Bidang Pembangunan Dewan Perwakilan Rakyat Kabupaten (DPRK) Pidie Jaya, dan Akademisi Universitas Syiah Kuala.

\subsection{Teknik Pengumpulan Data Kuesioner}

Kuesioner penelitian ini terbagi atas dua bagian, yaitu kuesioner bagian A, dan kuesioner bagian B.Kuesioner bagian A bertujuan untuk menanyakan tentang perbandingan kriteria berpasangan, sedangkan kuesioner bagian $\mathrm{B}$ bertujuan untuk menanyakan tentang perbandingan alternatif berpasangan. Pengukuran jawaban kuesioner bagian A dan bagian B menggunakan skala Saaty yaitu penilaian perbandingan berpasangan. Pengumpulan data kuesioner dilakukan dengan menjumpai langsung tempat keberadaan responden dan memberikan formulir kuesioner.

\subsection{Teknik Analisis Data}

Analisis data digunakan Analytical Hierarchy Process (AHP) sebuah konsep untuk membuat keputusan berbasis multikriteria (kriteria yang banyak). Beberapa kriteria yang dibandingkan satu dengan lainnya (tingkat kepentingannya) merupakan penekanan utama pada konsep ini dan menjadi sebuah metode penentuan atau pembuatan keputusan, yang menggabungkan prinsip-prinsip subjektifitas dan objektifitas di pembuat Sistem Pendukung Keputusan (SPK) atau keputusannya (Utama, 2017). Hirarki AHP meliputi tujuan, kriteria, dan alternatif, tujuannya untuk mengidentifikasi kriteria yang dominan perlu dipertimbangkan dan untuk menentukan urutan prioritas. Kriterianya adalah meliputi kerusakan jalan, biaya peningkatan, dan tata guna lahan. Justifikasi terhadap kriteria:

1. Kriteria kerusakan jalan ditinjau dengan pertimbangan lokasi usulan yang mempunyai panjang permukaan rusak berat perlu diprioritaskan peningkatan jalan, sehingga dapat memberikan pelayanan yang mantap bagi pengguna jalan. 
2. Kriteria biaya peningkatan ditinjau dengan pertimbangan lokasi usulan yang mempunyai biaya terendah perlu diprioritaskan peningkatan jalan, sehingga ketersediaan anggaran sanggup mengakomodir peningkatan yang dimaksud.

3. Kriteria tata guna lahan ditinjau dengan pertimbangan lokasi usulan yang banyak melewati lahan produktif (kawasan pertanian, kawasan perkebunan, dan kawasan perikanan) perlu diprioritaskan peningkatan jalan, sehingga hasil bumi banyak dapat diangkut oleh masyarakat guna untuk ketahanan pangan.

Alternatifnya adalah meliputi Jalan Blang Dalam-Jurong Teungoh, Jalan Jeulanga Barat-Jeulanga Mata Ie, Jalan Simpang Pertanian-Cot Trieng-Rungkom, Jalan Trienggadeng-Panton Beurasan-Cubo, dan Jalan Meurandeh Alue-Asan Kumbang-Blang Miroe. AHP mempunyai beberapa tahapan yaitu sebagai berikut:

1. Membuat matriks perbandingan kriteria berpasangan berguna untuk mendapatkan sejumlah ouput seperti nilai eigen kriteria, jumlah nilai eigen kriteria, nilai rata-rata eigen kriteria, $\square$ maks kriteria, indeks konsistensi (CI) kriteria, dan rasio konsistensi (CR) kriteria.Output tersebut dihitung dengan cara sebagai berikut:

a. Nilai eigen kriteria dihitung dengan cara nilai skala suatu kriteria dikali dengan jumlah nilai skala semua kriteria secara vertikal yang terdapat pada matriks perbandingan kriteria berpasangan.

b. Jumlah nilai eigen kriteria dihitung dengan cara menjumlahkan nilai eigen masing-masing kriteria secara horizontal.

c. Nilai rata-rata eigen kriteria dihitung dengan cara jumlah nilai eigen kriteria dibagi dengan jumlah kriteria.

d. $\square$ makskriteria dihitung dengan cara jumlah nilai skala semua kriteria secara vertikal pada matriks perbandingan kriteria berpasangan dikali dengan nilai rata-rata eigen kriteria.

e. CI kriteria dihitung dengan cara hasil jumlah nilai $\square$ maks kriteria yang telah dikurangi jumlah kriteria, dibagi dengan hasil jumlah kriteria yang telah dikurangi 1.

f. CR kriteria dihitung dengan cara nilai CI kriteria dibagi dengan Indeks Random (IR).

Setelah memastikan semua persepsi responden konsisten melalui CR, maka nilai rata-rata eigen kriteria yang telah diperoleh sebelumnya dapat digunakan dan dihitung nilai rata-rata gabungan eigen kriteria. Nilai rata-rata gabungan eigen kriteria dihitung dengan cara nilai rata-rata eigen kriteriaantar responden dijumlahkan lalu dibagi dengan jumlah responden (5). Nilai rata-rata gabungan eigen kriteria tertinggi menunjukkan kriteria yang dominan perlu dipertimbangkan dalam peningkatan jalan di Kabupaten Pidie Jaya.

2. Membuat matriks perbandingan alternatif berpasangan berguna untuk mendapatkan sejumlah ouput seperti nilai eigen alternatif, jumlah nilai eigen alternatif, nilai rata-rata eigen alternatif, $\square$ maks alternatif, CI alternatif, dan CR alternatif. Output tersebut dihitung dengan cara seperti pada matriks perbandingan kriteria berpasangan yang telah diuraikan sebelumnya.Setelah memastikan semua persepsi responden konsisten melalui $\mathrm{CR}$, maka nilai ratarata eigen alternatif yang telah diperoleh sebelumnya dapat digunakan dan dihitung nilai rata-rata gabungan eigen alternatif. Nilai rata-rata gabungan 
eigenalternatif dihitung dengan cara nilai rata-rata eigen alternatifantar responden dijumlahkan lalu dibagi dengan jumlah responden (5).

3. Menentukan urutan prioritas alternatif dilakukan dengan cara mengalikan nilai rata-rata gabungan eigen dari matriks perbandingan kriteria berpasangan dengan nilai rata-rata gabungan eigen dari matriks perbandingan alternatif berpasangan. Hasil perkalian nilai rata-rata gabungan eigen antar matriks tersebut, yang tertinggi hingga terendah menunjukkan ruas jalan yang menjadi urutan prioritas peningkatan di Kabupaten Pidie Jaya berdasarkan kriteria kerusakan jalan, biaya peningkatan, dan tata guna lahan.

\section{Hasil dan Pembahasan}

\subsection{Matriks Perbandingan Kriteria Berpasangan}

Sebelum nilai rata-rata eigen kriteria digunakan lebih lanjut, maka perlu memastikan semua persepsi responden mempunyai jawaban yang konsisten, dimana nilai CR kriteria harus $<0,1$. Dalam hal ini seluruh persepsi responden mempunyai nilai $\mathrm{CR}$ kriteria $<0,1$, sehingga seluruh persepsi responden dinyatakan konsisten dalam memberikan penilaian tingkat kepentingan antar kriteria. Selanjutnya nilai rata-rata eigen kriteria dari seluruh responden, perlu dicarikan nilai rata-rata gabungan eigen kriteria. Adapun nilai rata-rata gabungan eigen kriteria dari seluruh responden dapat dilihat pada Gambar 2.

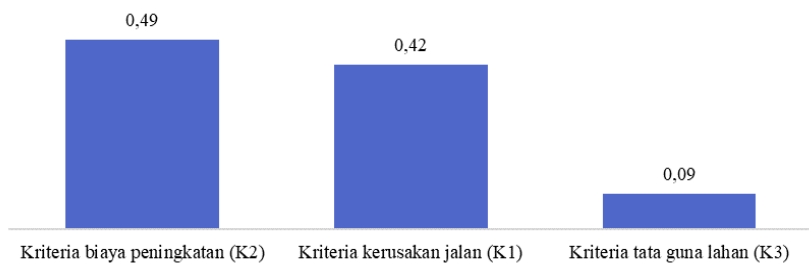

Gambar 2Nilai rata-rata gabungan eigen kriteria

Gambar 2 memperlihatkan bahwa nilai rata-rata gabungan eigen kriteria tertinggi didapat pada kriteria biaya peningkatan sebesar 0,49 , hal ini berarti bahwa kriteria yang dominan perlu dipertimbangkan dalam peningkatan jalan di Kabupaten Pidie Jaya menurut persepsi stakeholders adalah kriteria biaya peningkatan. Kriteria biaya peningkatan menjadi pertimbangan utama dalam peningkatan jalan, dikarenakan selama ini Pemerintah Daerah cenderung mendapat anggaran yang terbatas, sehingga orientasi peningkatan jalan menyesuaikan dengan jumlah anggaran yang ada, terlebih saat ini, dampak dari pandemi covid 19, pemerintah pusat telah melakukan refocusing DAK fisik pada masing-masing bidang. Selain kriteria biaya peningkatan, urutan kriteria lainnya yang perlu dipertimbangkan dalam peningkatan jalan di Kabupaten Pidie Jaya menurut persepsi stakeholders adalah kriteria kerusakan jalan dengan nilai ratarata gabungan eigen kriteria sebesar 0,42 , dan kriteria tata guna lahan dengan nilai rata-rata gabungan eigen kriteria sebesar 0,09.

Hasil penelitian ini terdapat perbedaan dengan 8 penelitian terdahulu. Kriteria yang dominan perlu dipertimbangkan dalam pengembangan jaringan jalan pendukung kawasan strategis di Pulau Sumbawa adalah kriteria aksesibilitas dengan bobot sebesar 0,31 (Afriansyah et al., 2012). Kriteria yang dominan perlu 
dipertimbangkan dalam penanganan ruas jalan nasional Bireuen-LhokseumawePanton Labu adalah kriteria volume lalu lintasdengan bobot sebesar 0,39 (Risdiansyah et al., 2014). Kriteria yang dominan perlu dipertimbangkan dalam pemeliharaan jalan kabupaten di wilayah perkotaan Tanjung Redeb adalah kriteria kondisi jalan dengan bobot sebesar 0,42 (Antoro et al., 2016). Kriteria yang dominan perlu dipertimbangkan dalam pengembangan jaringan jalan pendukung Rencana Induk Pelabuhan (RIP) di Provinsi Aceh adalah kriteria efektifitas dalam mendukung pengembangan wilayah dengan bobot sebesar 0,44 (Ramli et al., 2017). Kriteria yang dominan perlu dipertimbangkan dalam penanganan jalan luar kota Kabupaten Pacitan adalah kriteria kondisi jalan dengan bobot sebesar 0,56 (Handayani et al., 2017). Kriteria yang dominan perlu dipertimbangkan dalam pembangunan jalan di Kabupaten Aceh Jaya adalah kriteria sosial dengan bobot sebesar 0,28 (Fuadi et al., 2018). Kriteria yang dominan perlu dipertimbangkan dalam penanganan jalan di Kabupaten Timor Tengah Selatan adalah kriteria kawasan strategis dengan bobot sebesar 0,20 (Nope et al., 2018). Kriteria yang dominan perlu dipertimbangkan dalam penanganan jalan di Kabupaten Pidie adalah kriteria kerusakan jalan dengan bobot sebesar 0,20 (Thantawi, 2019).

Hasil penelitian ini terdapat persamaan dengan 2 penelitian terdahulu.Kriteria yang dominan perlu dipertimbangkan dalam pengembangan jaringan jalan di Kabupaten Lembata adalah kriteria pembiayaan dengan bobot sebesar 0,24 (Ignasius et al., 2014). Kriteria yang dominan perlu dipertimbangkan dalam pemeliharaan jalan di Kabupaten Karanganyar adalah kriteria biaya penanganan dengan bobot sebesar 0,44 (Sushera et al., 2019).

\subsection{Matriks Perbandingan Altenatif Berpasangan}

Matriks perbandingan alternatif berpasangan dari seluruh responden pada dasarnya bertujuan untuk mendapatkan nilai rata-rata eigen alternatif. Dalam penerapannya, sebelum nilai rata-rata eigen alternatif digunakan lebih lanjut, maka perlu memastikan semua persepsi responden mempunyai jawaban yang konsisten, dimana nilai CR alternatif harus $<0,1$. Dalam hal ini seluruh persepsi responden mempunyai nilai $\mathrm{CR}$ alternatif pada masing-masing kriteria $<0,1$, sehingga seluruh persepsi responden dinyatakan konsisten dalam memberikan penilaian tingkat kepentingan antar alternatif. Selanjutnya nilai rata-rata eigen alternatif dari seluruh responden, perlu dicarikan nilai rata-rata gabungan eigen alternatif.Adapun nilai rata-rata gabungan eigen alternatif dari seluruh responden dapat dilihat pada Gambar 3.

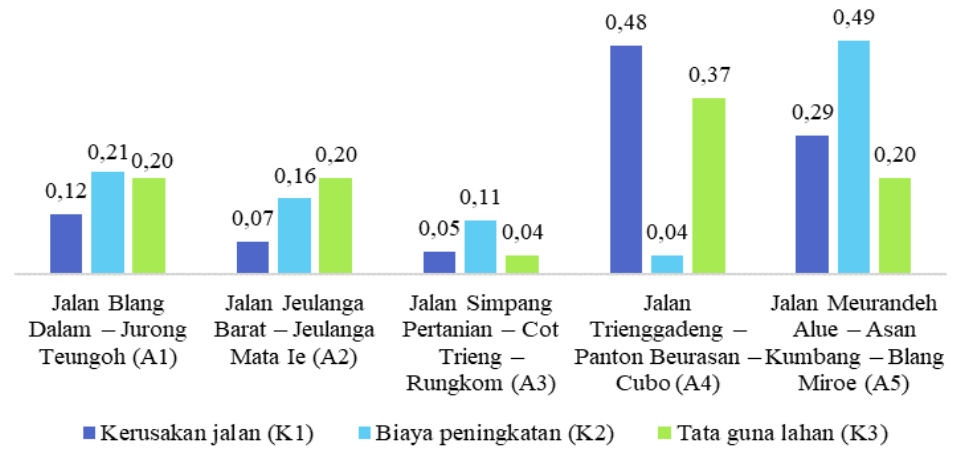

Gambar 3 Nilai rata-rata gabungan eigen alternatif pada masing-masing kriteria

Prioritas Peningkatan Jalan di Kabupaten Pidie Jaya Berbasis Analytical Hierarchy Process (AHP) - Y. Mahendra, R. Anggraini, A. T. Bulba 
Gambar 3 memperlihatkan bahwa bila dilihat dari kriteria kerusakan jalan, peningkatan jalan yang perlu diprioritaskan adalah Jalan Trienggadeng-Panton Beurasan-Cubo dengan bobot sebesar 0,48. Bila dilihat dari kriteria biaya peningkatan, peningkatan jalan yang perlu diprioritaskan adalah Jalan Meurandeh Alue-Asan Kumbang-Blang Miroe dengan bobot sebesar 0,49. Bila dilihat dari kriteria tata guna lahan, peningkatan jalan yang perlu diprioritaskan adalah Jalan Trienggadeng-Panton Beurasan-Cubo dengan bobot sebesar 0,37.

\subsection{Urutan Prioritas Alternatif}

Hasil perkalian antar nilai rata-rata gabungan eigen (bobot) yang tertinggi hingga terendah menunjukkan ruas jalan yang menjadi urutan prioritas peningkatan di Kabupaten Pidie Jaya. Adapun urutan prioritas alternatif peningkatan jalan dapat dilihat pada Tabel 2.

Tabel 2 Urutan prioritas alternatif

\begin{tabular}{|c|c|c|c|c|c|}
\hline \multirow{3}{*}{ Kriteria } & \multicolumn{3}{|c|}{$\begin{array}{c}\text { Nilai Rata-rata } \\
\text { Gabungan Eigen } \\
\text { Kriteria } \\
\end{array}$} & \multirow{3}{*}{$\begin{array}{c}\text { Hasil } \\
\text { Perkalian } \\
\text { Antar } \\
\text { Nilai }\end{array}$} & \multirow{3}{*}{$\begin{array}{l}\text { Prioritas } \\
\text { Alternatif }\end{array}$} \\
\hline & K1 & K2 & K3 & & \\
\hline & 0,42 & 0,49 & 0,09 & & \\
\hline \multirow[t]{2}{*}{ Alternatif } & \multicolumn{3}{|c|}{$\begin{array}{l}\text { Nilai Rata-rata } \\
\text { Gabungan Eigen } \\
\text { Alternatif }\end{array}$} & $\begin{array}{l}\text { Rata-rata } \\
\text { Gabungan } \\
\text { Eigen }\end{array}$ & \\
\hline & K1 & K2 & K3 & & \\
\hline Jalan Blang Dalam - Jurong Teungoh & 0,12 & 0,21 & 0,20 & 0,17 & 3 \\
\hline Jalan Jeulanga Barat - Jeulanga Mata Ie & 0,07 & 0,16 & 0,20 & 0,12 & 4 \\
\hline $\begin{array}{l}\text { Jalan Simpang Pertanian - Cot Trieng - } \\
\text { Rungkom }\end{array}$ & 0,05 & 0,11 & 0,04 & 0,08 & 5 \\
\hline Jalan Trienggadeng - Panton Beurasan - Cubo & 0,48 & 0,04 & 0,37 & 0,25 & 2 \\
\hline $\begin{array}{l}\text { Jalan Meurandeh Alue - Asan Kumbang - } \\
\text { Blang Miroe }\end{array}$ & 0,29 & 0,49 & 0,20 & 0,38 & 1 \\
\hline Jumlah & 1,00 & 1,00 & 1,00 & 1,00 & \\
\hline
\end{tabular}

Tabel 2 memperlihatkan bahwa urutan prioritas peningkatan jalan di Kabupaten Pidie Jaya berdasarkan kriteria kerusakan jalan, biaya peningkatan, dan tata guna lahan dari seluruh persepsi stakeholders adalah Jalan Meurandeh Alue - Asan Kumbang - Blang Miroe sebagai prioritas 1 dengan bobot sebesar 0,38, Jalan Trienggadeng - Panton Beurasan - Cubo sebagai prioritas 2 dengan bobot sebesar 0,25, Jalan Blang Dalam - Jurong Teungoh sebagai prioritas 3 dengan bobot sebesar 0,17, Jalan Jeulanga Barat - Jeulanga Mata Ie sebagai prioritas 4 dengan bobot sebesar 0,12, dan Jalan Simpang Pertanian - Cot Trieng - Rungkom sebagai prioritas 5 dengan bobot sebesar 0,08. Penentuan batas prioritas perlu ditetapkan karena total biaya peningkatan jalan seluruh alternatif sebesar Rp. 16.731.593.750, sudah direfocusing oleh Pemerintah Pusat menjadi sebesar Rp. 9.666.880.000. Oleh karena itu penentuan batas prioritas ditetapkan dengan memilih beberapa alternatif yang mempunyai total biaya peningkatan tidak melebihi total anggaran yang sudah direfocusing. Adapun pemilihan batas prioritas peningkatan jalan ini dapat dilihat pada Tabel 3 . 
Tabel 3 Pemilihan batas prioritas

\begin{tabular}{|c|c|c|c|c|c|}
\hline No. & Alternatif & Volume & $\begin{array}{c}\text { Biaya } \\
\text { Pembangunan }\end{array}$ & Prioritas & $\begin{array}{c}\text { Pemilihan } \\
\text { Prioritas }\end{array}$ \\
\hline 1 & Jalan Blang Dalam - Jurong Teungoh & $1,00 \mathrm{~km}$ & Rp. 3.200.000.000 & 3 & Tidak Dipilih \\
\hline 2 & $\begin{array}{l}\text { Jalan Jeulanga Barat - Jeulanga } \\
\text { Mata Ie }\end{array}$ & $1,02 \mathrm{~km}$ & Rp. 3.270.400.000 & 4 & Tidak Dipilih \\
\hline 3 & $\begin{array}{l}\text { Jalan Simpang Pertanian - Cot Trieng } \\
\text { - Rungkom }\end{array}$ & $0,75 \mathrm{~km}$ & Rp. 3.300.000.000 & 5 & Tidak Dipilih \\
\hline 4 & $\begin{array}{l}\text { Jalan Trienggadeng - Panton } \\
\text { Beurasan - Cubo }\end{array}$ & $1,80 \mathrm{~km}$ & Rp. 5.760.000.000 & 2 & Dipilih \\
\hline \multirow[t]{2}{*}{5} & $\begin{array}{l}\text { Jalan Meurandeh Alue - Asan } \\
\text { Kumbang - Blang Miroe }\end{array}$ & $0,45 \mathrm{~km}$ & Rp. 1.201.193.750 & 1 & Dipilih \\
\hline & Jumlah & & Rp. 16.731.593.750 & & \\
\hline
\end{tabular}

Tabel 3 memperlihatkan peningkatan jalan berdasarkan kriteria kerusakan jalan, biaya peningkatan, dan tata guna lahan hanya dapat dipilih 2 alternatif yaitu Jalan Meurandeh Alue-Asan Kumbang-Blang Miroe yang masuk prioritas 1 sepanjang 0,45 km dan Jalan Trienggadeng-Panton Beurasan-Cubo yang masuk prioritas 2 sepanjang $1,80 \mathrm{~km}$. Alternatif tersebut dipilih karena total biaya peningkatan jalan ketika dijumlahkan tidak melebihi total anggaran yang sudah di-refocusing yaitu sebesar Rp. 9.666.880.000. Alternatif Jalan Meurandeh AlueAsan Kumbang-Blang Miroe sebagai prioritas 1 mempunyai biaya peningkatan Rp. 1.201.193.750 dan alternatif Jalan Trienggadeng-Panton Beurasan-Cubo sebagai prioritas 2 mempunyai biaya peningkatan sebesar Rp. 5.760.000.000. Total biaya peningkatan untuk 2 alternatif tersebut adalah sebesar Rp. 6.961.193.750. Sementara, sisa biaya dari Rp. 9.666.880.000 yaitu sebesar Rp. 2.705.686.250 dapat dialokasikan untuk penanganan jalan lainnya yang mencakup pemeliharaan jalan dan konstruksi baru. Alternatif yang masuk dalam prioritas 3, 4, dan 5 tidak dapat dilakukan peningkatan karena keterbatasan anggaran.

\section{Kesimpulan dan Saran}

\subsection{Kesimpulan}

Kriteria biaya peningkatan jalan merupakan criteria dominan yang perlu dipertimbangkan dalam peningkatan jalan di Kabupaten Pidie Jaya dengan nilai rata-rata gabungan eigen sebesar 0,49. Prioritas peningkatan jalan di Kabupaten Pidie Jaya berdasarkan kriteria kerusakan jalan, biaya peningkatan, dan tata guna lahan adalah Jalan Meurandeh Alue-Asan Kumbang-Blang Miroe sebagai prioritas 1 dengan bobot sebesar 0,38 dan Jalan Trienggadeng-Panton BeurasanCubo sebagai prioritas 2 dengan bobot sebesar 0,25 .

\subsection{Saran}

Saran sebagai bentuk rekomendasi bagi Pemerintah Kabupaten Pidie Jaya adalah perlu mempertimbangkan kriteria biaya peningkatan, agar peningkatan jalan dapat menyesuaikan dengan refocusing anggaran dari pemerintah pusat. Disarankan juga untuk memprioritaskan Jalan Meurandeh Alue - Asan Kumbang Blang Miroe dengan biaya peningkatan sebesar Rp. 1.201.193.750 dan Jalan Trienggadeng-Panton Beurasan-Cubo dengan biaya peningkatan sebesar Rp. 5.760.000.000, sehingga total biaya peningkatan kedua jalan tersebut tidak melebihi Rp. 9.666.880.000 yang sudah direfocusing oleh pemerintah pusat. 


\section{Daftar Kepustakaan}

Afriansyah, R., Wicaksono, A., Djakfar, L., 2012. Penentuan Prioritas Pengembangan Jaringan Jalan Pendukung Kawasan Strategis di Pulau Sumbawa. Rekayasa Sipil 6, 214-225.

Anggoro, D.D., 2017. Pajak Daerah dan Retribusi Daerah. Universitas Brawijaya Press, Malang.

Antoro, J.B., Djakfar, L., Wicaksono, A., 2016. Penentuan Prioritas Pemeliharaan Jalan Kabupaten di Wilayah Perkotaan Tanjung Redeb, Kabupaten Berau. Rekayasa Sipil 10, 1-9.

Fuadi, R., Isya, M., Anggraini, R., 2018. Analisa Skala Prioritas Proyek Pembangunan Jalan di Kabupaten Aceh Jaya. J. Arsip Rekayasa Sipil dan Perenc. 1, 22-29.

Handayani, D., Hartono, W., Firdausy, S., 2017. Prioritas Penanganan Jalan Luar Kota Kabupaten Pacitan. Matriks Tek. Sipil 5, 243-251.

Ignasius, G., Djakfar, L., Anwar, M.R., 2014. Studi Penentuan Prioritas Pengembangan Jaringan Jalan di Kabupaten Lembata - Provinsi NTT. Rekayasa Sipil 8, 30-40.

Nope, F.J.S., Djakfar, L., Anwar, M.R., 2018. Model Prioritas Penanganan Jalan (Studi Kasus di Kabupaten Timor Tengah Selatan, NTT). JUTEKS J. Tek. Sipil 2, 149-157.

Ramli, M., Saleh, S.M., Anggraini, R., 2017. Studi Pengembangan Jaringan Jalan Pendukung Rencana Induk Pelabuhan (RIP) di Provinsi Aceh. J. Tek. Sipil Univ. Syiah Kuala 1, 143-156.

Risdiansyah, Isya, M., Saleh, S.M., 2014. Studi Penentuan Prioritas Penanganan Ruas Jalan Nasional Bireuen - Lhokseumawe - Panton Labu. J. Tek. Sipil Pascasarj. Univ. Syiah Kuala 3, 50-61.

Sushera, V., Rohman, M.A., Kartika, A.A.G., 2019. Analisis Prioritas Pemeliharaan Jalan Kabupaten Karanganyar Metode Analytical Hierarchy Process (AHP). J. Transp. Sist. Mater. dan Infrastruktur 1, 95-99.

Thantawi, 2019. Penentuan Skala Prioritas Penanganan Jalan Kabupaten Pidie Menggunakan Metode Analisis Multi Kriteria (AMK). Universitas Syiah Kuala.

Utama, D.N., 2017. Sistem Penunjang Keputusan: Filosofi Teori dan Implementasi. Garudhawaca, Yogyakarta.

Copyright (c) Yusril Mahendra, Renni Anggraini, Alfa Teras Bulba

Prioritas Peningkatan Jalan di Kabupaten Pidie Jaya Berbasis Analytical Hierarchy Process (AHP) - Y. Mahendra, R. Anggraini, A. T. Bulba 